\title{
Identity Formation and Discourse of Power: A Study of Us, Them and Othering in Nervous Conditions
}

\author{
Fahmida Manzoor ${ }^{1} \&$ Fouzia Rehman Khan ${ }^{2}$ \\ ${ }^{1}$ Department of English, Sardar Bahadur Khan Women University, Quetta, Pakistan \\ Correspondence: Fahmida Manzoor, Department of English, Sardar Bahadur Khan Women University, Quetta, \\ Pakistan. E-mail: fehmanz@gmail.com
}

\author{
Received: February 28, 2018 Accepted: April 11, 2018 Online Published: April 24, 2018 \\ doi:10.5539/ijel.v8n4p262 URL: https://doi.org/10.5539/ijel.v8n4p262
}

\begin{abstract}
This study was designed to trace the deconstruction of authoritative officialized history in fiction through Postmodern Historigraphic Metafiction. Historiographic Metafiction dismantles the metanarrative of official history and raises the voice of silenced subaltern thus generates mininarratives. The study is thus grounded in Postmodern Historiographic Metafictional theory of Linda Hutcheon for investigation of the "subversive strategies" of officialized history and deconstruction of positively accentuated binary of "us" and negatively accentuated binary of "them" in the backdrop of postcolonial literary text Nervous Conditions. Norman Fairclough's model of Critical Discourse Analysis is taken up as a research method for the analysis of fictionalized historical work under study. Finally, text is analyzed leading to the conclusion of the study. The study shows that fiction unveils the official overriding history and provides new perspectives of untold historical events.
\end{abstract}

Keywords: identity formation, discourse of power, deconstruction

\section{Introduction}

The process of colonialism punctuated the identity of marginalized subject with a big question mark and made him dwell in the hybrid space sometimes willingly or mostly unwillingly. Colonial oppression brought colossal drastic change in the notion of "self" of the colonized subject. This study thus aims to explore the identity crisis of the colonized and marginalized subjects depicted in Tistsi Dangarembga's fictional work Nervous Conditions and further draws a critical discourse analysis of those "silent other" subjects in the backdrop of colonial rule. Fairclough's approach of Critical Discourse Analysis is selected for the analysis of textual structures which highlight the discursive practices that shape identities of superior and inferior.

Discourse (Language ) according to Norman Fairclough (1989) is a social practice which determines the power relations in a social setup hence the focus on social relations and social practice raises the questions of collective and individual identity on one hand and the power hierarchy, ideological constructions, its consequences and subject positions on the other. It also generates questions like how identity construction is done by groups, individuals and institutes. How are ethnic, gender, religious and racial identities negotiated and represented? How is other or out-group delineated discursively and how are power relations represented and enacted through discourse? According to Norman Fairclough (2003), ideologies are both socially inculcated and enacted in the identities of social agents. The colonizers through the strategic use of discourse maintained power and domination on one hand and subjugation and suppression through social and physical dominance on the other. Identity is a continuous process shaped through discourse and social interaction in a social setup. The meaning of existence in a social setup is discursively generated as the racial, subaltern identities are not the pre-existing characteristics of individual but constructed in discourse.

\subsection{Research Objectives}

The research objectives of this study are as follows:

1) To scrutinize marginalized identity construction through discourse and its effect both on individuals and communities in Nervous Conditions.

2) To investigate the deconstruction of colonial history through fiction reflected in Nervous Conditions. 


\subsection{Research Questions}

This study will investigate the following research questions:

1) How is colonial history fictionalized and deconstructed in Nervous Conditions?

2) How are the suppressed identities constructed through discourse of power in Nervous conditions?

\section{Literature Review}

The postcolonial writers explore the cultural and political history written or unwritten by the overriding narrative of authorized official history. Postcolonial writers seek to bring to the front the narratives of history which dismantle the binaries on the basis of which colonialists built their literal and ideological empires. The postcolonial discourse destabilized the grand narrative of history by bringing in plurality of competing multiple voices from history. Postcolonial writers argue that history can never be a compilation of the facts about the real events rather it is subjective interpretation of the events. We choose the stories which suit us the most from our memory to remember in the same way nations and societies select those stories which suit their ideologies the best for the definition of group identity. Postcolonial writers argue that the silenced voice and small stories of the native could be heard and seen outside the western mainstream.

Colonialism was not merely a conquest of geographical territories rather a complete subjectivation of the native identities in the colonized regions. With the colonizer's suppressive hegemonic strategies the native's notion of self-suffered a radical alteration. Native's identity was changed through the discursive practices in the colonized territories. The term identity has relational characteristics as according to social psychology it underlines the relation of individual to the society. Identity is the notion of self in relation to the society and awareness of one's standing in the society as Burke \& Stetes (2009) illustrate in their seminal work Identity Theory:

An identity is the set of meanings that define who one is, when one is an occupant of a particular role in society, a member of a particular group, or claims particular characteristics that identify him or her as a unique person. For example, individuals have meanings that they apply to themselves when they are a student, worker, spouse, or parent (these are roles they occupy), when they are a member of a fraternity, when they belong to the Democratic Party, when they are Latino (these are memberships in particular groups), or when they claim they are outgoing individuals or moral persons (these are personal characteristics that identify themselves as unique persons. (p. 3)

The individual is connected to the society with his behavior patterns so both individual and society have a dialectical relationship. The relationship of individual to society involves "structural symbolic interaction" which mainly focuses on three main concepts, language, interaction and self. This term structural symbolic interaction is coined by Stryker to focus on the concept of agent to the society. According to Stryker (1980), it is the identity which links individual to the social structures as identities are the designations which people have in a social structure. (p. 26)

In the social structure, it is the discourse of power which shapes identities thus creates a standard hierarchy of identities with the notion of "us" and "them". The colonial process in different regions of the world constructed subaltern identities with discursive strategies and discourse of power. The colonized thus evaluated himself on the basis of identity standard set by the colonizers and resulted in a low self-esteem and self-perception which caused distress as discussed above in Burke and Stets theory. Edward Said (1979) illustrates the strategies through which the colonizers defined themselves and the colonized as an oppositional other to them. The Western Orientalists legitimized their operation by defining themselves as "occident" and labeled the colonized as "orient". Said (1979) unveils the Western strategies and the purposeful misrepresentations of the Orient by the Western scholars. Orient is set of imaginative ideas, values and a geographical location which is constructed to explain the self-identity/occident thus is a mirror image and reflection of marginal, native, inferior and other to the occident. The colonizers with the discourse of power infused their ideologies in such a strategic hegemonic way that the colonized nations started considering themselves inferior to the occident. Colonized minds were controlled in a way that they started believing in the supremacy and richness of colonial religion, education, culture and traditions. The whole process of colonization was done by the slogan "I know my native" according to Chinua Achebe (as cited in Ashcroft, Griffiths, \& Tiffin, 1999, p. 58) as he illustrates in his essay "Colonialist Criticism",

To the colonialist mind it was always of the utmost importance to be able to say: "I know my natives" claim which implied two things at once (a) that the native was really quite simple and (b) that understanding him and controlling him went hand in hand-understanding being a precondition for control and control constituting adequate proof of understanding. 
The colonized identity was subjugated and constructed as uncivilized through the infusion of certain ideologies. The sheer efforts to be identified with the occident/empire created a chaos and fragmentations in the identities of the colonized marginalized people. They underwent through a harsh experience of loss of identity, dislocation and placelessness and this anxiety and horror was faced by all subjugated, marginalized colonized nations. The archetype of colonial subjugation of mind rests on some specific practices. The colonizers transmuted their belief systems through the support of strong power structures. The colonizers overrated the "occidental" authority and devalued the subjugated other and through these maintained schemes of vicious coercion claimed authority over natives. They were succeeded in "colonization of native mind" through persuasive process and a hegemonic transmission of such beliefs and ideologies in native mind. The basic and main ingredient was the implicit reception by the colonized native of the "rule of inference" which mechanically granted superiority to the reasons and warrants of the colonizer. According to this strategic rule, when the colonized compared his ideology and beliefs to the colonizer he found the colonizer's ideologies and beliefs preferable and tried to adopt them and started considering himself inferior. The identity of native is constructed as other through the discourse of power and according to Edward Said (1979) the complete process of orientalism should be studied as a discourse in Foucaultian tradition as he postulates,

Without examining Orientalism as a discourse one cannot possibly understand the systematic discipline by which European culture was able to manage-and even produce-the Orient politically, sociologically, militarily, ideologically, scientifically, and imaginatively during the Post-Enlightenment period. (p. 3)

These discourses of occident serve the hegemonic powers and give rise to the power relations. The whole process of subjectivation and suppression was done by the notion of "knowledge and power" as West claimed knowledge of Orient "I know my native" and constructed the Orient as inferior to the occident. Said (1979) illustrates the way they (colonizers) ruled the orient by idea of "know them better" which was their self-created notion as for Balfour the "British knowledge of Egypt is Egypt for Balfour" (cited in Said, 1979, p. 32). The notion of "knowing" became a kind of tool through which west infused their language, ideology, education as a part of their civilizing mission. The colonial discourse defined the identity of native in binary oppositions such as occident/orient, black/white, self/other, us/them, colonizer/colonized, definer/defined. West draw these binary oppositions and represented abnormalities, faults and eccentricities in the colonized "other" just to draw a self-image in opposition to that as a normal, standard and virtuous being as Spivak (as cited in Ashcroft, Griffiths, \& Tiffin, 1999) argues "in the context of colonial production, the subaltern has no history and cannot speak" (p. 287). Fanon (1967) in his book Black Skin White Masks elaborates the psychological state of native mind after colonial influences in psycho-analytical perspectives. The influence of colonialism on native mind is severe and turned the native subjects into identity crisis. Frantz Fanon (1967) in his Black Skin, White Mask illustrates some case studies about the mental agony and stress of the colonized identity and says,

A Negro tells me his dream: "I had been walking for a long time, 1 was extremely exhausted, 1 had the impression that something is waiting for me, 1 claimed barricades and walls, 1 came into an empty hall, and from behind a door 1 heard noise. I hesitated before I went in, but finally I made up my mind and opened the door. In this second there were white men, and I found that I too was white". (p. 99)

According to Fanon (1967), the inferiority is created and fabricated in native mind by the disastrous burial of its own original local culture. The task of colonizing native's mind was accomplished through language as the natives were forced to speak in English in schools and children were being punished in different ways for speaking their own native language in colonized territories. According to Ngugi (1986), language and culture are mutually constitutive so the cultural training of the native was accomplished through the linguistic training. In consequence of that English language became a symbol of knowledge, prosperity, success and progress and the native language a symbol of ignorance, shame, failure and regression and this thus resulted in "the disassociation of the sensibility of that child from his natural and social environment, what we might call colonial alienation" ( $\mathrm{p}$. 17). This according to Spivak (as cited in Ashcroft, Griffiths, \& Tiffins, 1999) is an "epistemic violence" (p. 25), a term she borrowed from Michal Foucault which illustrates the hegemony of colonizers. The native identity underwent a critical crisis in result of the suppression and subjugation. Jamaica Kincaid (as cited in Ashcroft, Griffiths, \& Tiffins, 1999) elaborates the colonial process in her works thoroughly and highlights the suppressive strategies of colonizers through which they constructed the inferior other. According to Jamaica Kincaid (1999), this suppression of identity created a crisis in native's soul as she says,

And so everywhere they went they turned it into England; and everybody they met they turned English. But no place could ever really be England, and nobody who did not look exactly like them would ever be English, so you can imagine the destruction of people and land that came from that ... the Antigua I grew up in revolved almost completely around England ... I met the world through England, and if the world 
wanted to meet me it would have to do so through England. (p. 94)

The identity of native was changed because of the influence of colonialism. The people who used to live with great harmony in their native land were displaced and the harmony got disturbed through infusion of the colonial ideologies.

\section{Theoretical Framework}

This study analyses the text under postmodern theory of historiographic metafiction and deconstruction of meta narratives. It focuses on the main characteristic of historiographic metafiction such as parody and intertexuality through which the fictional writers subvert the meta narrative of history. Postmodern historigraphic metafiction is a good tool in the perspective of postcolonial literature as it responds to Eurocentric forms and kinds of knowledge which are completely based on ethnocentric cultural and ideological assumptions. The excavation of the mini narratives creates new knowledge and undermines the authoritative conventional hegemony of occident over historical records. The insertion of petit recits (mini narratives) into history broadens the horizon of remembered past knowledge and at the same time brings to the fore many more previously overlooked histories. In the traditional historical accounts, while one story is exposed or recorded countless histories remain silent and doomed to be buried untold and lost. The excavation of the untold past has a healing effect as it talks about the lost inheritance of the subaltern subjects thus resists to the dominating discourses. The Postmodern historigraphic metafiction opens space for the multiple mini narratives which don't conform to the conventional ideologies valued by euro centrism rather enables the multiple "silenced" and "othered" voices from different cultures hence allows the historical experiments and incidents to be heard. The existence of past in historiographic metafiction is never disputed rather it affirms that the access to past is obtainable only through language as Linda Hutcheon (1988) postulates,

History is not made obsolete: it is, however, being rethought-as a human construct. And in urging that history doesn't exist except as text, it does not stupidly and "gleefully" deny that the past existed, but only that its accessibility to us now is entirely conditioned by textuality. (p. 16)

The notion about past is always subjective as it involves subjective acts and factors such as, the selection, construction and evaluation of specific past events. Thus in this vein Historigraphic Metafiction asserts that historical meanings don't lie in the events rather in the systems which subjectively construct them for ideological purposes.

\subsection{Research Method}

This study aims to investigate the data through Fairclough's (1992) approach of Critical Discourse Analysis as CDA is an analysis of the dialectical relationships between discourse and other elements of social practices. (p. 11). Fairclough's (2003) approach focuses on the use of power and transmission of ideologies which construct different identities of dominated and subordinate. (p. 18)

This study investigates the underlying core ideologies embedded and rooted in the structures of the narratives. Fairclough's approach is employed to the present study as it carries multidimensional analysis and enables the assessment of the dialectical relationship of narrative text with the society. This present research scrutinizes the works under study through following analytical framework of Fairclough (1989):

1) Discourse as a text investigates the linguistic elements of the overall narrative construction (identity construction/reconstruction) as a counter-discourse to the power. (p. 111)

2) Discourse as a Discursive Practice involves the role of the writers as producers of the narrative text/discourse and the role of the reader as the consumer of the text. The narrative text/discourse is addressed to the consumers (the general public) to shape opinions, normalize and regulate behaviors. (p. 116)

\section{Data Analysis}

Nervous Conditions is set in the backdrop of Rhodesia in late 1960's and early 1970's before the independence highlights the conditions of native and the aftermath of colonial rule. The novel narrates the history of Rhodesian's plight under colonial rule and the devastating effects of colonial reign on the lives of native. The novel opens up with the news of protagonist Tambu's brother's death. Tambu doesn't feel sad about her brother Nhmao's death because he used to live away from home in a missionary school. Tambu's only desire in life is to study but her family can't afford her education because of poverty. Tambu's uncle Babamukuru who has fully adopted the English ways visits Tambu's place and asks her parents to let Tambu replace Nhmao in the missionary school. Babamukur's daughter Nysha is shown disturbed because of the dual cultures. The novel ends on the frustrating feelings of Nyesha and other characters. Each character is shown disturbed and nervous 
about the Englishness of society. The novel narrates history through different perspectives thus deconstructs the traditional official history of colonialism. The title of the novel is taken from Sartre's preface to Fanon's most famous work The Wretched of Earth in which he states "the condition of native is a nervous condition" (Fanon, 1963, p. 20). Dangarembga illustrates the nervous conditions of the native identity in colonial Rhodesia through different mini narratives. Nervous conditions metafictionaly breaks the reader's frame of "suspended disbelief" and makes him ponder about the status of fiction and fact in the narration. Metafiction works self-consciously on the process of production as an artifact and further complicates it by mixture of historical events thus makes the reader able to assign different meanings to the status of historical truth in the light of fictive elements. It blurs the line between fact and fiction and breaks the frame of fiction self-reflexively and makes it difficult for the reader to differentiate between the fact and fiction. Dangarembga subverts the metanarratives of domination by giving voice to the suppressed class of society. The characters are shown suffering greatly the pangs of colonialism in different ways. Each character has a different story and is shown greatly influenced by the "Englishness" of the white culture. The whole society suffers the heavy burden of "Englishness" but still craves for the opportunities to adopt "Englishness". Dangarembga (2004) illustrates the colonial strategies through which the colonizers ruled the native hegemonicaly. The exercise of power by the colonizers resulted in trauma and identity crises in native characters. Dangarembga (2004) shows consequences of colonial suppression which resulted in violence in native subjects. Each character inflicts pain on other inferior to him in the power hierarchy because of the disturbed state of mind caused by colonial oppression. Nervous Conditions (2004) narrates the history from marginal perspectives thus provides and alternative history with the amalgamation of fictive characters. Positioned in Rhodesia on the edge of Independence the novel focalizes the complexities of colonialism and the educational strategies through which the colonizers controlled the native hegemonicaly. Dangarembga narrates the historical facts of the colonial history through fictional characters and breaks the frame of the reality as a fictional construct too. Tambu, the protagonist of the novel narrates the Southern Rhodesian history of colonialism through her life experiences. Her idea about the colonizers comes from the knowledge passed to her by her grandmother and brother Nhamo and according to her,

The Whites on the mission were a special kind of white person, special in the way that my grandmother had explained to me, for they were holy. They had come not to take but to give. They were about God's business here in darkest Africa. They had given up the comforts and security of their own homes to come and lighten our darkness. It was a big sacrifice that the missionaries made. It was a sacrifice that made us grateful to them, a sacrifice that made them superior not only to us but to those other Whites as well who were here for adventure and to help themselves to our emeralds. (p. 105)

The situational contexts in the quoted text are the colonial contents and the subject relation between the colonizers and colonized. The description of white people in the text narrates the history of Rhodesia and the colonial strategies of education thus presents a picture of whole colonized society. According to Fairclough (1989) the situational contexts for all discourses include "the system of social and power relationship at the highest, societal level. Just as even a single sentence has traditionally been seen to imply a whole language, so a single discourse implies a whole society" (p. 152). Tambu's assumption about the holy white man ironically sheds light on the colonial strategies through which they hegemonicaly subjugated the native subjects. Tabmu's understanding of the missionaries comes from her life in Rhodesia where natives craved to get a chance to be educated in white ways. The missionary school system started in Africa in 1890 by Cecil John Rhodes with the European occupation. According to him, mission "work as one of the best means for opening up and civilizing a country" (as cited in Schmidt, 1992, p. 123). The mission schools were not only for academic purposes but they taught natives "cleanliness and orderliness" as the main idea which was rooted in colonial mind was the dirty and savage, retarded native who needs to be civilized by the white man thus was considered a white man's burden. Tabmu's assumption of white person as a "holy" and "superior" person illustrates the system of social and power relationship at the highest, societal level. The native was given the inferior position as the dirty savage as David Goldberg (2002) asserts that "Racial rule is accordingly taken to be legitimated in virtue of the assumption that non-Europeans are inherently inferior to Europeans, indeed, so inferior as to be incapable for the most part of self-governance" (p. 82). Through Tabmu's fictive character Dangarembga illustrates the historical events in colonial Rhodesia thus breaks the frame of fiction by blurring the status of both fact and fiction.

\subsection{Intertextuality in Nervous Conditions}

The quoted text illustrates the historical "intertexts" of colonial Rhodesia and breaks the presuppositions of the readers about colonial dominant discourse. Tambu's words They were about God's business here in darkest Africa are the "intertexts" of history which shed light on the colonial purpose of rule in Rhodesia. The colonial notion of the black native as inferior strengthened the plan of the education in the colonized places to civilize and 
educate the barbaric savage. To inculcate the civilized Christian manners in the black uncivilized native the mission schools were established in different colonies to spread the word of God and superior religion to the inferior people of inferior religions. Darkest Africa is used metaphorically to shed light on the dominant discourses which constructed the power relations on the binary of superior us and inferior them thus subjugated the native subject. Through the power of discourse the white was symbolized as superior and black inferior in the colonial dominant discourse. Dangramebga's words darkest Africa ironically deconstruct the dominant discourse thus write back to the empire to normalize the behavior of the consumers of text.

The quoted text sheds light on the larger scale texts which exist inside the text that are the colonial schemes of rule and native's scheme of resistance. The frame of reality is constructed through the historical text which highlights the historical events in Rhodesia. The educational strategies of the colonizers are stated in the text with the apparently holy mission to spread the word of God in the darkest Africa which makes them "superior" to all races for their service to God and humanity. The native is compelled to believe through the power of hegemony that the good superior ways are the white ways which teach to be civilized and cultured. The ones who teach the natives these lessons are the superior, special and holy people. Dangarembga breaks the historical frame of reality through Tabmbu's fictive characters and poses questions to the "greedy" nature of white people in the next statement. She resists the dominant colonial discourse by putting the colonial self-assumptions in Tambu's mouth but then resists by showing colonial real strategies which were indirect as she says "It was a big sacrifice that the missionaries made. It was a sacrifice that made us grateful to them, a sacrifice that made them superior not only to us but to those other Whites as well who were here for adventure and to help themselves to our emeralds" (p. 105). She narrates the history through different mini narratives which focus on different aspects of the colonial rule as on one hand she shows the missionaries who are serving in the name of God but were inculcating their culture, language and religion in native subjects and on the other hand the white who were enjoying the wealth of native by subjugating the native economically. By highlighting the colonial strategies Dangarembga unveils the history and raises the voice of subaltern subjects thus regulates the behavior of readers as consumers of the text.

\subsection{Stories within Stories in Nervous Conditions}

Nervous Conditions depicts the colonial rule and its cultural practices the British colonizers imposed on native subjects which made them forget willingly and unwillingly their culture, native language Sohna and belief systems. The English manners, language, culture were made to be considered superior emblems of superiority and social prestige. The hegemony of the colonizers disturbed the native identity and forces them to adopt the new cultural ways and identity to be considered superior in the social hierarchy. The colonizers considered native inferior and barbarous whose identity should be groomed and reshaped based on European standards. The colonizers legitimized their presence in the colonized regions for these purposes thus subjugated the native subject to maintain power through the slogan of civilization. Dangarembga subverts the traditional history narrated by the power structures thus raises the voice of native suppressed subjects. She unveils subaltern history through metafictional narrative technique and narrates stories with in stories to deconstruct the overriding traditional accounts of history. Mbuya narrates different stories of past to Tambu in a Chinese box pattern as Tambu recounts:

She gave me history lessons as well. History that could not be found in the textbooks; a stint in the field and a rest, the beginning of the story, a pause. "What happened after, Mbuya, what happened?" More work, My child, before you hear more story. "slowly, methodically, throughout the day the field would be cultivated, the episodes of my grandmother's own portion of history strung together from beginning to end . . . the wizards well versed in treachery and black magic came from the south and forced the people from the land." (pp. 17-18)

The quoted passage is relevant in the situational context of the text as it illustrates the history in a metafictional technique and subverts the status of "superior white" in the social setup. Mbuya, Tabmu's grandmother narrates her stories about the wizards who invaded native land and displaced the native subjects. Mbuya and Tambu relate to the diegetic (primary) world of the Chinese box world in which Tambu works hard in her field with the help of her grandmother to generate money so to get admission in the mission school and get educated in the white ways. Mbuya further narrates another story about the wizards and their treachery which transfers the focus from diegetic world to the hypo-diegetic world. The white wizards in the hypo-diegetic world snatch away the land of the native thus brought destruction to the native inhabitants. The relationship between the diegetic and hypo-diegetic worlds is that of superior and inferior as the white wizards the "civilized" colonizers who invaded the land and controlled the natives through different strategies. The relation between the colonizer and colonized is based on the self-assumed definition of the colonizer as they forced the people from the land. Mbuya doesn't 
possess positive feelings about the white people as she uses negative words to describe the white but at the same time she helps Tambu in the field to cultivate so that Tambu gets money to pay her fee at the mission school and gets educated in the white ways. The white education and culture was considered a symbol of superiority and prosperity. Dangarembga as a producer of this text narrates the colonial history from a periphery perspective to reregulate the behaviors of the consumers of text.

The quoted excerpt illustrates the "intertextual contexts" of the text and further highlights the "presuppositions" based on the colonial dominant discourse. Dangarembga unveils colonial history through historic narration of Mbuya to her granddaughter Tambu. The version of Mbuya's history can't be found in the text books because the textbooks are written by the pen of power as Tambu records "she gave me history lessons as well. History that could not be found in the textbooks". The intertext of history narrated through the subjugated subaltern subjects break the presuppositions of the dominant discourse hence deconstruct the traditional accounts of history. The colonizers who are documented as the most cultured and civilized are labeled wizards who with their black magic and treachery displaced the natives from their land. The heroic notion (presupposition) of the colonizer is subverted through the historical intertext from the marginal perspective in the quoted text both in the diegetic and hypo-diegetic nested narratives.

\subsection{Us / Them and Othering in Nervous Conditions}

In the postcolonial scenario, the notion of identity focuses on one's definition of self in the context of quickly changing society. How does a person define himself? How do environment, language, history and politics of the foreign culture influence him? The notion of self traditionally is derived from one's past, culture and education thus an individual positions himself in the society in the light of these factors. The sense of individual and collective identity of the colonized subjects got disturbed because of the disrespecting colonial culture and force. The education system was replaced by the colonizers who infused their tradition and culture thus replaced the glory of native past in to the superiority of the colonizer culture and traditions. The dominated culture made it difficult for the native sense of self to find a niche in the stigmatized society. Tsitsi Dangarembga's Nervous Condition describes the first hand records of colonial experiences during the colonial encounter with the British Empire. It portrays the disturbed experiences of colonial era of colonization and the consequences of the pattern of life under the historical and cultural change. Dangarembga speaks back to the dominant discourse and exposes the veiled sufferings of the colonized subjects. She depicts the difficult atmosphere of the colonialism, suppression, discrimination and domination and its effects on the native. Through her narration she revels the facts which are not given space in the traditional historical books thus challenges the dominant discourse. Nervous Conditions highlights the question of native identity, resistance and trauma in the context of colonial era and illuminates the strategies through which the subjugated identity is formed and constructed through discourse of power. Through many characters in the novel Dangarembga depicts the construction of subjugated silenced subaltern identity in the colonial context. The novel starts depicting the colonial influence on a native character Nhamo who suffers a nervous condition between the local and foreign culture thus feels irritated and humiliated of local culture. He tries to adopt the foreign superior culture of the colonizer completely and started looking down at his people, culture, language and ways of life as Tambu narrates about him,

This was the walk that my brother detested! Truly . . . Yet resentful he was, and most of the time he managed to avoid it by staying at the mission after the end of term . . My uncle insisted that Nhamo be home for it on the grounds that there were no examinations pending to justify his staying at the mission. Thus Nhamo was forced once a year to return to his squalid homestead, where he washed in cold water in an enamel basin or flowing river, not in a bathtub with tapes gushing hot water and cold; ate sadza regularly with his fingers and meat hardly at all, never with a knife and fork; where there was no light beyond the flickering yellow of candles and homemade paraffin lamps to escape into his books when the rest of us had gone to bed. All this poverty began to offend him, or at the very least embarrass him after he went to the mission, in a way that it had not done before. Before he went to the mission, we had been able to agree that although our squalor was brutal, it was uncompromisingly ours; that the burden of dispelling it was, as a result ours too. (pp. 4-6-7)

The quoted excerpt narrates that how the notion of self gets fragmented by the appropriation of colonial culture. The colonial culture pushes the individual into many directions adopting an identity which created a chaos in their character. Nhamo's character highlights the experiential values of the text as his identity is constructed discursively in this context of colonialism. Tambu's comments about Nhamo's detesting behavior for his culture and people illuminates the classifying schemes of the colonizer through which the native was subjugated and alienated from his own local culture. The colonial strategies created a chaos in native mind by colonizing his mind thus left them in sheer "nervous conditions". Tambu's comments about Nhamo's hatred and humiliation for 
the local culture is constructed by the dominant discourse of colonizer as the moment he got admission in the mission school he felt alienated from his own culture as Tambu says, "This was the walk that my brother detested! Truly ... Yet resentful he was, and most of the time he managed to avoid it by staying at the mission after the end of term". The words resentful and detested shed light on the aspect of native hybridity and the reality of chaotic situation which is built on the ideologies of colonizer. The resentful and detested feelings were built in the native subject (Nhamo) through the dominant discourse of mission education. The structure of the words detested and resentful are ideologically based as the colonial climate is responsible for constructing native identities in this way where they feel mortified of their very own culture they have been born in and living on for many years. Through stereotype assumptions the native identity is naturalized and universalized as inferior by the colonial dominant discourses and discursive strategies. According to Tambu's comments Nhamo was so resentful of home that "most of the time he managed to avoid it by staying at the mission after the end of term". The concept of home is traditionally associated to comfort but in Nhamo's case it is different because he tries to adopt the colonial ways of life thus feels detested and resentful of home, culture, and all native ways.

Tambu's comments about Nhamo's behavior highlight the euphemistic expressions of the text as this indirectly shows the colonial discursive strategies which constructed Nhamo's identity as a subaltern subjugated subject. Through formal use of words Tambu unveils the identity of her brother Nhamo who was disturbed by the colonial education. Nhamo didn't want to visit home where everything makes him feel inferior and felt more comfortable in white ways of living as Tambu asserts, "Thus Nhamo was forced once a year to return to his squalid homestead, where he washed in cold water in an enamel basin or flowing river, not in a bathtub with tapes gushing hot water and cold". The word forced here depicts the euphemistic expression of the colonial ideology which distorted the native self-image to such an extent that they were forced to visit home once a year and felt detested and humiliated in home and home culture. Squalid homestead are the words which illuminate native feelings of dejection for home as home is now associated with discomfort in Nhamo's case because his identity is transformed and he feels better to associate himself to the superior colonizer group by adopting their culture.

In the web of this quoted text the struggle of the powerful and powerless is highlighted as the native is imprisoned in the strong snare of foreign dominated culture which affected his identity in a very devastating way. The colonial discourse associated self with the superior behaviors which intensified the position of other as an inferior subject which is visible in character of Nhamo. The assumption of colonial culture as superior is infused so strongly in native mind that eating sadza with hand is considered near to a sin to Nhamo (a colonized subject). The culture of fork and knife is preferred over the native culture of eating sadza with fingers. Through these metaphorical expressions Dangarembga highlights the construction of native identity as an inferior other subject in the colonial context.

The quoted excerpt highlights the larger scale structures exist in the text that is of colonizer and colonized. The colonized subject's reality is constructed through different discursive strategies of the colonizer. Nhamo's perception of social reality as an inferior subject is constructed discursively. The construction of colonial culture as superior legitimizes and reinforces the colonial authority over native subject. As Tambu comments "All this poverty began to offend him, or at the very least embarrass him after he went to the mission, in a way that it had not done before. Before he went to the mission, we had been able to agree that although our squalor was brutal, it was uncompromisingly ours; that the burden of dispelling it was, as a result ours too". The things which belong to home embarrass Nhamo after he has joined the mission; his sense of self is completely changed when he encountered the foreign culture and education. Before the encounter they own their culture strongly instead of its shortcomings but the encounter with the foreign dominant culture punctuated the sense of self in native subjects. The colonial ideologies are used as a tool of power for constructing unequal relations which forced the native strategically to think of himself as inferior other of the dominant colonial culture.

Nervous Conditions narrates the story of struggle trauma, identity crisis, struggle, resistance, submission, assimilation and domination in the colonized Rhodesia. The colonial imaginary representations were transmitted in native subjects through different colonial discursive strategies which served the dominant and motivated the native to accept himself as constructed and represented in the colonial ideologies. According to Althusser, these ideological practices are "ideological state apparatuses" (qtd. in Asmat, Hayat, \& Qasim, 2012, p. 44) which serve to form subjects who accept willingly the privileged system of the hegemonic dominant. To reinforce the control over native the colonizers chose the most shining and intellectual individuals to lure them in the culture of dominant (colonizer) so to make them "good munts" who accept the system willingly and put efforts to entrench it. Babamukuru's character evidently highlights the embracing role of a good colonized subject who serves the mission of colonizers by infusing and reinforcing European ideologies into the native subjects of his 
clan. He prefers Christian ways on his native belief system and insists on a Christian marriage of Jeremiah and Ma'Shingayi thus reinforces us and them ideology. Babamukuru's character is portrayed ironically in Nervous Conditions as apparently he seems a perfect man but in fact he is not and he also suffers the "nervous conditions" of colonialism severely as Tabmu comments,

For from my grandmother's history lessons, I knew that my father and brother suffered painfully under the evil wizard's spell. Babamukuru, I knew was different. He hadn't cringed under the weight of his poverty. Boldly, Babamukuru had defied it. Through hard work and determination he had broken the evil wizard's spell. Babamukuru was now a person to be reckoned with his own right. He didn't need to bully anybody any more. Especially not Maiguru, who was so fragile and small she looked as though a breath of wind could carry her away. Nor could I see him bullying Nyasha. My cousin was pretty and bold and sharp. You never thought about Babamukuru as being handsome or ugly, but he was completely dignified. He didn't need to be bold anymore because he had made himself plenty of power. Plenty of power, a lot of education, plenty of everything. (p. 50)

Tambu's over wording evil wizard illuminates the experiential values of the text as through the choice of vocabulary she highlights two different kinds of identities which are constructed under colonial rule. The spell of evil wizard makes Jeremiah and Nhamosuffer the pangs of colonialism and construct their social identity as inferior native. On the other hand Babamukuru is shown different because he adopts the colonial ways completely and breaks the evil spell as Tambusays, Through hard work and determination he had broken the evil wizard's spell. The use of synonymous words like hard work and determination illuminate the experiential values of the text and highlight the ideology of the colonizer which through different strategies constructed inferior subjugated identities. Babamukuru's character is silenced as he doesn't have his own agency as a native individual rather speaks in the voice of the colonizer. His mimicry of the dominant culture is termed as hard work and determination which can be the watchwords to enter the realm of prosperity. The dominant culture of colonizer was represented as a symbol of prosperity and happiness to the native subjects and the one who assimilates completely in the culture can get the prosperous life as is evident in Babamukuru's case. In this process of cultural assimilation the native loses his identity and becomes what he is not. Babamukur's identity is constructed discursively which doesn't in fact lead to success as he encounters many problems in his life inside his family. He is represented as a shallow character who is apparently dignified but inside shallow as he treats his wife and daughter badly under the garb of civilization. Through Babamukuru's character Dangarembga highlights the shallowness of the white culture which seems dignified apparently but are broken and shallow inside. The rewording in Tambu's description of Babamukuru's plenty of everything is ironical when she says $\boldsymbol{h e}$ had made himself plenty of power. Plenty of power, a lot of education, plenty of everything. The plenty of everything that is power education and money refers to the plenty of whiteness which destroyed the native culture and constructed broken identities like Nayasha and Babamukuru.

The quoted excerpt highlights the relational values of the text as it portrays Babamukuru's character in a euphemistic way. Through the use of formal words and euphemistic expressions Babamukuru's (a colonized subject) negativity is mitigated. Babamukuru's identity as a colonized subject is subjugated and whatever he speaks is colonizer's voice thus he reinforces the colonial agenda into native subjects by associating himself with the colonizer's culture. Babamukuru's identity is described in formal words which ironically highlight the colonial strategies of subject construction as Tambu says a person to be reckoned with his own right. The choice of formal words in the quoted statement about Babamukuru are euphemistic as the opposite of this is that he doesn't have his own individuality and agency and speaks in the voice of adopted dominant culture. The choice of formal words through which Tambu describes Babamukuru's identity are again euphemistic expressions as she says, he was completely dignified. He was opposite to this an artificial dignified instead of complete dignified character.

Babamukur's identity is representative of the educated native elite who neither belongs to local culture nor to the foreign dominant culture. The evaluative words through which Tambu describes Babamukuru's identity highlight the expressive values of the discourse as she says He didn't need to bully anybody anymore. Because he has adopted the white ways of life so the presupposed notion about him as an epitome of whiteness is that he shouldn't bully to get rid of his depression for being an inferior native. But he acts metaphorically the opposite way and bullies both Nayasha and Maiguru and all his native clan under his authority. The subordinate characters to Babamukuru are Nayasha and Maiguru who are described in the evaluative words. Maiguru is fragile and small while Nayasha is Bold, sharp and pretty who should never get bullied by the complete dignified Babamukuru. Through the metaphorical evaluative words Tambu describes the identity construction of Babamukuru under colonial rule. His identity is constructed as a civilized man under colonial education which 
he is not in real as he exploits his bold, sharp and pretty daughter Nayasha and fragile and small wife Maiguru.

The quoted passage highlights larger scale structures exist in the discourse. The colonial mental representations are highlighted through the history narrated by Tambu's grandmother as she says, "For from my grandmother's history lessons, I knew that my father and brother suffered painfully under the evil wizard's spell". The history lessons narrate the sufferings of the colonized subjects under the evil wizard's spell. Through this evil spell the identity of native is constructed as other of the dominant European colonizer. According to the history lessons, Babamukuru was sent to the white people to adopt the white ways so to break the spell of evil wizards. The notion of self is disturbed because of the encounter with the wizards who disturbed the harmony of native life and subjugated native subjects to maintain their power over them.

\section{Conclusion}

The analysis of data highlights that the fact that fiction deconstruct the official history and presents multiple versions of history focusing on the subaltern point of view. A nervous condition unveils the history from below and opens up stories of marginal characters like Tambu. Nhamo, Nyesha and Babamukuru. Tsitsi Dangarembga sheds light on identity construction through discursive practices. Nyesha is a true representative of "them" identity constructed through the discursive practice of whites. Dangarembga highlights the fact that the whole process of identity formation of us and them is done through discourse. Through her fiction Nervous Conditions Dangarembga dissects the social and institutional factors and power structures which influenced the native mind as an individual and a nation. Colonialism brought a cultural conflict because of the cultural contacts as the colonizers claimed a superiority of race and culture over the suppressed society thus generated the issues of cultural identities in the native subjects. This cultural conflict made majority of the native alien at their own place which is recorded in the selected works as the native has resisted and glorified its culture and customs in comparison to the dominant culture. Nervous Conditions destabilizes the grand narrative of white superiority by raising black voice. Her characters suffer the racial discrimination by the colonizers in various ways. Every individual in Nervous Condition is greatly influenced by the Englishness of white culture. Dangarembga shows the infectious influence of white culture on native subjects who suffer greatly by the Englishness but doesn't miss any opportunity to adopt English white ways. She resists to the superiority of Englishness by highlighting its disastrous effects on native individual and national cultural identity.

\section{References}

Achebe, C. (1999). Colonialist Criticism. In B. Ashcroft, G. Griffiths, \& H. Tiffin (Eds.), The Post-colonial Studies Reader (pp. 57-61). London: Routledg.

Burke, P. J., \& Jan, E. S. (2009). Identity Theory. Oxford: Oxford University Press. https://doi.org/10.1093/acprof:oso/9780195388275.001.0001

Dangarembga, T. (2004). Nervous Conditions. Oxfordshire, UK: Ayebia Clark Publishing Ltd.

Fairclough, N. (2003). Analyzing Discourse. London: Routledge.

Fairclough, N. (1992). Discourse and Social Change. Cambridge: Polity Press.

Fairclough, N. (1989). Language and Power. New York: Longman.

Fanon, F. (1963). TheWretched of Earth. Paris: Africaine.

Fanon, F. (1967). BlackSkin, WhiteMasks. New York: Grove Press.

Goldberg, D. (2002). Racial Rules in Relocating Postcolonialism. Oxford: Blackwell Publishers Ltd.

Hutcheon, L. (2005). A Poetics of Postmodernism: History, Theory, Fiction. London: Routledge.

Hutcheon, L. (1988). Politics of Postmodernism. London: Routledge. https://doi.org/10.4324/9780203358856

Kincaid, J. (1999). A Small Place. In B. Ashcroft, G. Griffiths, \& H. Tiffin (Eds.), The Post-colonial Studies Reader (pp. 92-95). London: Routledg.

\section{Said, E. (1979). Orientalism. New York: Vintage.}

Schmidt, E. (1992). Peasants, Traders and Wives: Shona Women in the History of Zimbabwe 1873-1939. Portsmouth: Heinemann Educational Books.

Thiong, W. N. (1986). Decolonising the mind: the Politics of Language in African literature. London: Portsmouth. 


\section{Copyrights}

Copyright for this article is retained by the author(s), with first publication rights granted to the journal.

This is an open-access article distributed under the terms and conditions of the Creative Commons Attribution license (http://creativecommons.org/licenses/by/4.0/). 